\title{
DAMPAK BISNIS "PERIKANAN TANGKAP" DALAM MENUNJANG PENDAPATAN NELAYAN DI DESA KEDONGANAN JIMBARAN BADUNG BALI
}

\author{
Putu Ari Mulyani \\ ${ }^{1}$ Fakultas Ekonomi Universitas Mahendradatta, Bali, Indonesia \\ Email: arimulyani75@yahoo.com
}

\begin{abstract}
ABSTRAK
Negara Indonesia merupakan negara dengan luas laut terbesar, kita memiliki potensi untuk memanfaatkan hal tersebut demi kesejahteraan khususnya masyarakat nelayan. Namun, realitanya masyarakat belum mampu meningkatkan hasil produksi mereka, bahkan profesi sebagai nelayan cenderung identik dengan kemiskinan. Tingkat kesejahteraan para pelaku perikanan (nelayan) pada saat ini masih dibawah sektor-sektor lain, termasuk sektor pertanian agraris. Nelayan (khususnya nelayan buruh dan nelayan tradisional) merupakan kelompok masyarakat yang dapat digolongkan sebagai lapisan sosial yang paling miskin diantara kelompok masyarakat lain di sektor pertanian. Penelitian ini membahas faktor - faktor yang mempengaruhi pendapatan Nelayan di Desa Adat Kedonganan Jimbaran Kabupaten Badung.

Variabel yang dianalisis dalam penelitian ini adalah Modal (XI), Umur (X2), Curahan Jam Kerja (X3), Pengalaman Kerja (X4) dan Pendidikan (X5) analisis menggunakan analisis regresi linier berganda Hasil uji hipotesis bahwa pengaruh modal (X1) terhadap pendapatan nelayan. Tingkat signifikansi dari thitung sebesar 0.039 lebih kecil dari $\alpha=5$ persen (0.05). pengaruh umur (X2) terhadap pendapatan (Y) menunjukan tingkat signifikansi 0.642 lebih besar dari $\alpha=5$ persen (0.05). Berarti bahwa umur berpengaruh negatif dan tidak signifikan. jam kerja (X3) terhadap pendapatan (Y) menunjukan tingkat signifikansi 0.251 lebih besar dari $\alpha$ $=5$ persen (0.05). Berarti bahwa jam kerja tidak berpengaruh signifikan terhadap pendapatan nelayan, pengalaman kerja (X4) terhadap pendapatan (Y) menunjukan tingkat signifikansi 0.000 lebih kecil dari $\alpha=5$ persen (0.05). pendidikan (X5) terhadap pendapatan (Y) menunjukan tingkat signifikansi 0.383 lebih besar dari $\alpha$ $=5$ persen $(0.05)$.

Variabel umur, jam kerja dan pendidikan perlu mendapat perhatian dari pemerintah dimana dalam melakukan pekerjaan sebagai nelayan tidak hanya di ukur berdasarkan umur dan pendidikan saja tetapi juga keahlian atau keterampilan sebagai nelayan dalam menangkap hasil laut dengan menggunakan teknik - teknik tertentu dan perlengkapan yang memadai. Pemerintah Provinsi Bali dan dinas dinas terkait memberikan pelatihan - pelatihan kepada para nelayan dalam proses penangkapan hasil laut secara maksimal dengan metode - metode tertentu sehingga pengetahuan para nelayan dalam melakukan pekerjaan dapat secara maksimal sehingga hal tersebut akan menambah tangkapan hasil laut dan dapat menambah pendapatan para nelayan
\end{abstract}

Kata kunci : Pendapatan Nelayan, Modal, Umur, Jam Kerja, Pengalaman Kerja, Pendidikan 


\section{PENDAHULUAN \\ Latar Belakang}

Dari beberapa hasil studi menunjukkan bahwa masyarakat nelayan merupakan salah satu kelompok masyarakat yang secara intensif dilanda kemiskinan, kemiskinan tersebut disebabkan oleh faktor-faktor kompleks yang saling terkait serta merupakan sumber utama yang melemahkan kemampuan masyarakat dalam membangun wilayah dan meningkatkan kesejahteraan sosialnya. Kemiskinan yang dialami masyarakat nelayan juga dilatar belakangi oleh kurangnya modal dan teknologi yang dimiliki para nelayan, rendahnya akses pasar dan rendahnya partisipasi masyarakat dalam pengolahan sumber daya alam. Selain itu, ada juga penyebab lain yaitu faktor sosial seperti pertumbuhan jumlah penduduk yang tinggi, rendahnya tingkat pendidikan, dan rendahnya tingkat kesehatan serta alasan lain seperti sarana dan prasarana umum di wilayah pesisir.

Mengingat Negara Indonesia merupakan negara dengan luas laut terbesar, kita memiliki potensi untuk memanfaatkan hal tersebut demi kesejahteraan khususnya masyarakat nelayan. Namun, realitanya masyarakat belum mampu meningkatkan hasil produksi mereka, bahkan profesi sebagai nelayan cenderung identik dengan kemiskinan. Tingkat kesejahteraan para pelaku perikanan (nelayan) pada saat ini masih dibawah sektor-sektor lain, termasuk sektor pertanian agraris. Nelayan (khususnya nelayan buruh dan nelayan tradisional) merupakan kelompok masyarakat yang dapat digolongkan sebagai lapisan sosial yang paling miskin diantara kelompok masyarakat lain di sektor pertanian. Tingkat kesejahteraan masyarakat wilayah pesisir umumnya menempati strata yang paling rendah (miskin) dibandingkan dengan masyarakat lainnya di darat. Ditambah lagi dengan belum optimalnya kebijakankebijakan dari pemerintah yang cenderung lebih berorientasi kearah pengembangan sektor daratan.

Tingkat kesejahteraan nelayan sangat ditentukan oleh hasil tangkapannya atau yang biasa di sebut dengan produksi hasil tangkapan. Banyaknya tangkapan secara langsung juga berpengaruh terhadap besarnya pendapatan yang diterima hingga nelayan mampu memenuhi kebutuhan sehari-hari mereka. Hal ini dapat diartikan bahwa kebutuhan-kebutuhan hidupnya tersedia dan mudah dijangkau setiap penduduk sehingga pada gilirannya penduduk yang miskin semakin sedikit jumlahnya.

Kabupaten Badung yang terletak antara 5,3 - 5,33 derajat Lintang Selatan dan 119,22- 118,39 derajat Bujur Timur memiliki potensi kelautan dan perikanan yang cukup besar. Luas wilayah Kabupaten Badung adalah sekitar 566,51 km², dimana setengah wilayahnya atau sekitar 240,88 $\mathrm{km}^{2}$ diantaranya merupakan wilayah pesisir dengan panjang garis pantai sekitar $74 \mathrm{~km}$, yang berpotensi terhadap subsektor perikanan . Ditambah lagi produksi perikanan darat yang pada umumnya dilakukan melalui budidaya. Kontribusi subsektor perikanan terhadap PDRB Kabupaten Badung dari tahun ketahun mengalami 
peningkatan, walaupun tingkat dan merupakan sektor andalan pertumbuhan 3 berfluktuasi. Terlepas dibandingkan dengan sektor dan dari hal tersebut subsektor perikanan subsektor lainnya. Kontribusi tetap merupakan subsektor yang subsektor perikanan terhadap PDRB memiliki kontribusi paling besar Kabupaten Badung terlihat pada tabel terhadap PDRB Kabupaten Badung 1.1 berikut:

Tabel Kontribusi subsektor perikanan terhadap PDRB Kabupaten Badung atas dasar harga berlaku tahun 2009-2013

\begin{tabular}{ccc}
\hline Tahun & $\begin{array}{c}\text { Kontribusi subsektor perikanan } \\
\text { (Juta Rupiah) }\end{array}$ & $\begin{array}{c}\text { Persentase } \\
\text { (\%) }\end{array}$ \\
\hline 2009 & $187.849,83$ & 14,8 \\
2010 & $216.403,00$ & 15,2 \\
2011 & $250.464,83$ & 15,7 \\
2012 & $288.486,43$ & 15,1 \\
2013 & $318.962,49$ & 10,5 \\
\hline
\end{tabular}

Sumber : Badan Pusat Statistik Prov. Bali, 2015

Dari tabel diatas terlihat bahwa terjadi peningkatan kontribusi subsektor perikanan terhadap PDRB Kabupaten Badung dari tahun-ketahun. Pada tahun 2009 kontribusinya sebesar Rp $187.849,83$ juta meningkat menjadi Rp 318.962,49 juta di tahun 2013. Namun, berbeda dengan kontribusi yang terus meningkat, produksi perikanan khusunya di bidang perikanan tangkap laut Kabupaten Badung cenderung berfluktuasi pada 5 tahun terakhir. Berikut adalah tabel jumlah produksi tangkap Kabupaten Badung :

Tabel Jumlah Produksi Perikanan Tangkap Laut Kabupaten Badung tahun 2009-2013

\begin{tabular}{cl}
\hline Tahun & Jumlah Produksi (ton) \\
\hline 2009 & 28.325 \\
2010 & 33.420 \\
2011 & 25.590 \\
2012 & 4.243 \\
2013 & 4.251 \\
\hline \\
menyita perhatian pada tahun 2012 & penurunan tajam hasil produksi \\
terjadi penurunan produksi perikanan & perikanan tangkap. Hasil produksi \\
laut secara drastis yaitu hingga 5 kali & perikanan tangkap laut Tanjung \\
lipat dari produksi tahun 2011. & Benoa terlihat pada tabel berikut:
\end{tabular}


Tabel Jumlah Produksi Perikanan Tangkap Laut Tanjung Benoa tahun 2009-2013

\begin{tabular}{cc}
\hline Tahun & Jumlah Produksi (ton) \\
\hline 2009 & 3.854 \\
2010 & 5.516 \\
2011 & 4.185 \\
2012 & 934 \\
2013 & 963 \\
\hline \hline
\end{tabular}


Produksi atau hasil tangkapan nelayan merupakan salah satu faktor penentu atau faktor yang mempengaruhi pendapatan nelayan. Apabila produksi meningkat, pendapatan juga akan meningkat, begitu pula sebaliknya. Oleh karena itu, hal yang diharapkan adalah peningkatan jumlah produksi, akan tetapi berdasarkan data pada tabel 1.3 di atas, jumlah produksi hasil tangkapan di Tanjung Benoa justru mengalami penurunan di tahun 2011 dan 2012. Penurunan jumlah produksi yang terjadi di Tanjung Benoa yang dimulai pada tahun 2011 tersebut juga mengakibatkan penurunan pendapatan nelayan. Apalagi terjadi penurunan jumlah produksi yang tajam di tahun 2012, mengakibatkan masyarakat nelayan yang berada dalam belenggu kemiskinan, akan semakin miskin. Dari data yang tercatat di Badan Pusat Statistik Kabupaten Badung, Tanjung Benoa dengan jumlah penduduk sebesar 38.895 jiwa atau 10.209 Kepala Keluarga, Tanjung Benoa memiliki jumlah penduduk miskin sebesar 5.592 Kepala Keluarga, yang sebagian besar berprofesi sebagai nelayan dengan jumlah 5.153 nelayan tangkap. Jumlah penduduk miskin di Tanjung Benoaini termasuk yang terbesar dibandingkan kecamatankecamatan lain yang penduduknya ada yang bermata pencaharian sebagai nelayan tangkap di Kabupaten Badung. Penelitian ini akan mengamati dan menganalisis faktor-faktor yang mempengaruhi pendapatan nelayan tangkap. faktor yang mempengaruhi pendapatan nelayan meliputi faktor sosial dan faktor ekonomi terdiri dari besarnya modal, jumlah perahu, jumlah tenaga kerja, jarak tempuh melaut dan pengalaman. Kemudian ada pula faktor umur nelayan, pendidikan nelayan dan ukuran mesin yang digunakan.

\section{TINJAUAN PUSTAKA}

Perikanan adalah suatu kegiatan ekonomi yang tujuan pembangunannya untuk Indonesia adalah sebagai devisa negara, sumber pendapatan nelayan dan sumber protein hewani bagi manusia. Untuk mencapai tujuan-tujuan itu, produkproduk perikanan biasanya harus mengalami perpindahan pemilikan dari nelayan atau petani ikan sebagai produsen kepada penduduk sebagai konsumen. Perpindahan pemilikan yang dimaksud terjadi karena adanya pasar. Sebab itu pemasaran adalah mata rantai yang penting dalam suatu pembangunan perikanan (Evi, 2001). Ikan pada dasarnya merupakan sumber daya alam (sda) yang dikategorikan sebagai sda yang dapat diperbarui atau dipulihkan. Namun, hal ini tidak berarti bahwa sumber daya ikan tersebut dapat ditangkap secara sembarangan, misalnya dengan menggunakan bahan-bahan peledak atau menggunakan alat tangkap yang dapat mengakibatkan kerusakan lingkungan atau ekologi laut maupun melakukan tangkap lebih (over eksploitasi). Untuk mendukung pemulihan sumber daya ikan sangat diperlukan faktor pendukung lain, yakni faktor lingkungan laut atau ekologi laut, misalnya terumbu karang, yang meskipun terumbu karang ini dapat diperbaharui atau dipulihkan namun pemulihannya memerlukan waktu sangat lama dan biaya besar (Endang, 2011). 
Penangkapan ikan yang dilakukan nelayan secara kuantitas tergantung pada perahu, peralatan yang digunakan maupun faktor lain seperti musim air pasang. Dengan perahu dan peralatan tangkap yang sesuai dan layak dioperasikan maka hasil tangkapan menjadi lebih baik dan dapat memberikan jaminan hidup bagi rumah tangganya ( Samuelson dan Nordhaus (2001)

Tingkat pendapatan merupakan salah satu kriteria maju tidaknya suatu daerah. Bila pendapatan suatu daerah relatif rendah, dapat dikatakan bahwa kemajuan dan kesejahteraan tersebut akan rendah pula. Kelebihan dari konsumsi maka akan disimpan pada bank yang tujuannya adalah untuk berjaga - jaga. Demikian pula bila pendapatan masyarakat suatu daerah relatif tinggi, maka tingkat kesejahteraan dan kemajuan daerah tersebut tinggi pula (Boediono, 2000).

Pendapatan adalah seluruh penerimaan baik berupa uang maupun berupa barang yang berasal dari pihak lain maupun hasil industri yang dinilai atas dasar sejumlah uang dari harta yang berlaku saat itu. Pendapatan merupakan sumber penghasilan seseorang untuk memenuhi kebutuhan sehari - hari dan sangat penting artinya bagi kelangsungan hidup dan penghidupan seseorang secara langsung mau pun tidak lagsung (Suroto, 2000).

Faktor-Faktor yang Mempengaruhi Pendapatan Nelayan

1. Faktor yang berpengaruh secara Langsung Jumlah Tangkapan (Produksi) Ikan

Produktivitas merupakan jumlah barang atau jasa yang di hasilkan dalam satuan waktu (Mankiw,
2012). Salas (2004) menjelaskan kegiatan menambah nilai tambah atau nilai manfaat sesuatu barang dinamakan kegiatan memproduksi. Menurut Anom (2017) hubungan variabel input produksi dengan output (hasil produksi) merupakan fungsi produksi. Tentunya produksi dapat dijalankan melalui faktor sumberdaya alam, biaya produksi, manusia, dan skill (teknologi).

Menurut Ananta dalam maulana (2013) berpendapat kegiatan produksi tentunya memerlukan beberapa faktor atau variabel produksi, seperti perlengkapan dan peralatan dalam kegiatan memproduksi. Kegiatan memproduksi masyarakat nelayan. Nelayan menggunakan peralatannya untuk mendapatkan manfaat tambahan dengan cara digunakan untuk menangkap ikan sehingga nelayan akan mendapatkan pendapatan dari hasil tangkapan ikan.

2. Faktor yang Berpengaruh Secara Tidak Langsung

\section{a. Pengalaman}

Pengalaman adalah periode waktu bekerja sebagai nelayan selama masa hidupnya, pengalaman yang dimiliki akan berpengaruh pada produktivitas nelayan. Pengalaman adalah periode waktu bekerja sebagai nelayan selama masa hidupnya, pengalaman yang dimiliki akan berpengaruh pada produktivitas nelayan. Arliman (2013) menjelaskan human capital theory atau teori mutu modal manusia merupakan batas 
keahlian kemampuan dan wawasan yang dipunyai manusia juga memberikan pengaruh terhadap hasil produksi, apabila seseorang semakin ahli dalam bidangnya maka produksi yang dihasilkan akan semakin besar.

b. Lama melaut

Menurut penelitian yang dilakukan oleh Sukma (2014) menyatakan pengaruh jam kerja atau durasi melaut memiliki pengaruh positif terhadap penghasilan masyarakat nelayan dengan lama waktu melaut nelayan yang lebih lama maka nelayan tersebut akan memperoleh pendapatan yang lebih banyak. Azizi (2017) menyatakan lama melaut atau jam kerja melaut merupakan jumlah waktu yang dihabiskan nelayan dalam melakukan operasional penangkapan di laut yang bersifat one day fishing yang memiliki hubungan positif antara jam kerja melaut dan perubahan pendapatan.

c. Teknologi

\section{METODE PENELITIAN}

Teknik penentuan sampel yang digunakan adalah random sampling. Metode pengumpulan data yang digunakan dalam penelitian ini adalah metode Accidental Sampling. Penelitian ini menggunakan data sekunder yang bersumber dari Badan Pusat Statistik Provinsi Bali dan Dinas Pertanian Kabupaten Badung dan data primer yang digunakan penulis ialah data secara langsung bersumber dari responden.

$\mathrm{Y}=\beta 0+\beta 1 \mathrm{X} 1+\beta 2 \mathrm{X} 2++\beta 4 \mathrm{X} 3+\beta 5 \mathrm{X} 4+\beta 6 \mathrm{X} 5+\mathrm{e}$
Menurut Yuli (2016) secara umum pengaruh teknologi memberikan pengaruh positif terhadap output atau produksi. Tentunya jumlah tangkapan juga dipengaruhi oleh teknologi yang digunakan, menurut Rahman (2016) kurangnya teknologi juga merupakan salah satu penghambat dalam meningkatnya pendapatan nelayan.

d. Biaya Operasional Melaut Menurut Dahen (2016) makin besar biaya produksi melaut tentunya akan membuat makin besar pula kesempatan memperoleh tangkapan serta akan meningkatkan pendapatan nelayan. Sukartini (2003) biaya operasional dalam melaut yang berupa modal atau asset misalnya harga mesin kapal, harga perahu serta modal yang digunakan dalam kegiatan sekali melaut (makanan atau minuman dan bahan bakar yang digunakan).

\section{Analisis Linier Berganda}

Pada penelitian ini peneliti menggunakan metode analisis regresi berganda (multiple regression) karena penelitian ini menggunakan variabel multivariant dengan satu variabel dependen yang bersifat matrik. Metode analisis ini berguna untuk mengetahui seberapa besar pengaruh variabel independen terhadap variabel dependen. Model regresi linier berganda pada penelitian ini sebagai berikut 
Keterangan :

$\mathrm{Y}=$ Pendapatan Nelayan Desa

Kedonganan ( Rp)

$\mathrm{V} 0=$ Konstanta

$\beta 1, \beta 2, \beta 3, \beta 4 \& \beta 5=$ Koefisien regresi

$\mathrm{X} 1=$ Modal (unit)

$\mathrm{X} 2=$ Umur (tahun)

X3 = Curahan Jam Kerja (jam)

X4 = Pengalaman Kerja (tahun)

$\mathrm{X} 5=$ Pendidikan (tahun sukses)

$\mathrm{e}=$ Error (variabel bebas lain diluar model regresi)

\section{PEMBAHASAN}

PENELITIAN
Analisis Regresi Linier Berganda

Hasil regresi pengaruh modal (X1), umur (X2), jam kerja (X3), pengalaman kerja (X4), dan pendidikan (X5) terhadap pendapatan (Y) nelayan di Desa Kedonganan, Bali yang diperoleh oleh hasil olah data menggunakan program Statistical Product and Service Solution (SPSS) Versi 21.00 . Hasil tersebut kemudian menjadi dasar untuk menguraikan variabel bebas terhadap variabel terikat dalam penelitian ini dapat disajikan sebagai berikut.

Tabel Hasil Uji Pengaruh Modal, Umur, Jam Kerja, Pengalaman Kerja, dan Pendidikan Terhadap Pendapatan

\begin{tabular}{|c|c|c|c|c|c|c|c|c|}
\hline & \multirow[t]{2}{*}{ Model } & \multicolumn{2}{|c|}{$\begin{array}{l}\text { Unstandardized } \\
\text { Coefficients }\end{array}$} & \multirow{2}{*}{$\begin{array}{c}\text { Standardized } \\
\text { Coefficients } \\
\text { Betta } \\
\end{array}$} & \multirow[t]{2}{*}{$\mathrm{t}$} & \multirow[t]{2}{*}{ sig } & \multicolumn{2}{|c|}{ Collinearity Statistics } \\
\hline & & $B$ & Std. Error & & & & Tolerance & VIF \\
\hline \multirow[t]{6}{*}{1} & (Constant) & 9.146 & 1.871 & & 4.889 & .000 & & \\
\hline & Ln_x1 & .314 & .149 & .215 & 2.109 & .039 & .653 & 1.530 \\
\hline & $\operatorname{Ln} x_{2}$ & -.044 & .094 & -.079 & -.467 & .642 & .236 & 4.242 \\
\hline & Ln_X3 & .264 & .228 & .115 & 1.158 & .251 & .687 & 1.456 \\
\hline & $\operatorname{Ln}{ } \mathrm{X} 4$ & .164 & .041 & .672 & 4.040 & .000 & .245 & 4.081 \\
\hline & Ln_X5 & .020 & .023 & .085 & .878 & .383 & .732 & 1.365 \\
\hline
\end{tabular}


Jurnal Satyagraha, Vol. 02, No. 02, Agustus 2019 - Januari 2020 ISSN :2620-6358

Berdasarkan output SPSS diperoleh hasil bahwa modal, umur, jam kerja, pengalaman kerja, dan pendidikan berpengaruh secara simultan terhadap pendapatan nelayan di Desa Kedonganan, Bali Tahun 2018. Berdasarkan tingkat signifikansi dari Fhitung sebesar 0.000 yang lebih kecil dari $\alpha=5$ persen (0.05). Berarti bahwa tinggi rendahnya pendapatan nelayan di Desa Kedonganan, Bali dipengaruhi oleh modal, umur, jam kerja, pengalaman kerja, dan pendidikan.

Hasil uji hipotesis bahwa pengaruh modal (X1) terhadap pendapatan nelayan. Tingkat signifikansi dari thitung sebesar 0.039 lebih kecil dari $\alpha=5$ persen (0.05). Berarti bahwa modal berpengaruh signifikan terhadap pendapatan nelayan. Hasil uji menyatakan menerima H0 yang berarti modal berpengaruh terhadap pendapatan nelayan di Desa Kedonganan, Bali.

Berdasarkan output SPSS diperoleh hasil bahwa pengaruh umur (X2) terhadap pendapatan (Y) menunjukan tingkat signifikansi 0.642 lebih besar dari $\alpha=5$ persen (0.05). Berarti bahwa umur berpengaruh negatif dan tidak signifikan terhadap pendapatan nelayan. Nilai koefisien regresi umur (X2) sebesar -0.044 menunjukan adanya pengaruh negatif terhadap pendapatan nelayan.

Berdasarkan output SPSS diperoleh hasil bahwa pengaruh jam kerja (X3) terhadap pendapatan (Y) menunjukan tingkat signifikansi 0.251 lebih besar dari $\alpha=5$ persen (0.05). Berarti bahwa jam kerja tidak berpengaruh signifikan terhadap pendapatan nelayan. Nilai koefisien regresi jam kerja (X3) sebesar 0.264 menunjukan adanya pengaruh negatif jam kerja terhadap pendapatan nelayan.

Berdasarkan output SPSS diperoleh hasil bahwa pengaruh pengalaman kerja (X4) terhadap pendapatan (Y) menunjukan tingkat signifikansi 0.000 lebih kecil dari $\alpha=5$ persen (0.05). Berarti bahwa pengalaman kerja berpengaruh signifikan terhadap pendapatan nelayan. Nilai koefisien regresi pengalaman kerja (X4) sebesar 0.164 menunjukan adanya pengaruh positif pengalaman kerja terhadap pendapatan nelayan.

Berdasarkan output SPSS diperoleh hasil bahwa pengaruh pendidikan (X5) terhadap pendapatan (Y) menunjukan tingkat signifikansi 0.383 lebih besar dari $\alpha=5$ persen (0.05). Berarti bahwa pendidikan tidak berpengaruh signifikan terhadap pendapatan nelayan. Nilai koefisien regresi pendidikan (X5) sebesar 0.020 menunjukan adanya pengaruh negatif terhadap pendapatan nelayan.

\section{SIMPULAN DAN SARAN}

Berdasarkan pembahasan hasil analisis data penelitian dan mengacu pada tujuan penelitian yang sudah diuraikan pada bab pendahuluan, maka simpulan yang dapat disampaikan sekaligus yang dapat digunakan untuk menjawab rumusan masalah penelitian yang diajukan adalah sebagai berikut:

1) Secara simultan, variabel modal (X1), umur (X2), jam kerja (X3), pengalaman kerja (X4), dan pendidikan (X5) berpengaruh secara simultan terhadap pendapatan (Y) nelayan di Desa Kedonganan, Bali.

2) Variabel modal (X1), dan pengalaman kerja (X4) secara parsial berpengaruh positif dan signifikan terhadap pendapatan (Y) nelayan di Desa Kedonganan, Bali, sedangkan 
Jurnal Satyagraha, Vol. 02, No. 02, Agustus 2019 - Januari 2020 ISSN :2620-6358

umur (X2), jam kerja (X3), dan pendidikan (X5) secara parsial tidak berpengaruh signifikan terhadap pendapatan (Y) nelayan di Desa Kedonganan, Bali.

Berdasarkan simpulan yang telah diuraikan maka dapat diajukan saran sebagai berikut:

1) Variabel umur, jam kerja dan pendidikan perlu mendapat perhatian dari pemerintah dimana dalam melakukan pekerjaan sebagai nelayan tidak hanya di ukur berdasarkan umur dan pendidikan saja tetapi juga keahlian atau keterampilan sebagai nelayan dalam menangkap hasil laut dengan menggunakan teknik - teknik tertentu dan perlengkapan yang memadai.

2) Pemerintah Provinsi Bali dan dinas dinas terkait memberikan pelatihan pelatihan kepada para nelayan dalam proses penangkapan hasil laut secara maksimal dengan metode - metode tertentu sehingga pengetahuan para nelayan dalam melakukan pekerjaan dapat secara maksimal sehingga hal tersebut akan menambah tangkapan hasil laut dan dapat menambah pendapatan para nelayan.

\section{DAFTAR PUSTAKA}

Adhiatma, Alfian Arif. 2015. Pengaruh Modal Awal, Lama Usaha, Dan Jam Kerja Terhadap Pendapatan Pedagang Kayu Glondong Di Kelurahan Karang Kebagusan Kabupaten Jepara. Tugas Akhir Semester, Universitas Dian Nuswantoro Semarang.

Asakdiyah, Salamatun, Tina Sulistiyani, dan Deny Ismanto. 2015. Analisis
Pendapatan Usaha Pedagang Angkringan di Kota Yogyakarta. Jurnal Penelitian, 11: 117-125

Aryanto, Daniel Agustinus, dan Sudarti. 2017. Analisis Faktor-Faktor yang Mempengaruhi Pendapatan Buruh Nelayan di Pantai Sendangbiru Desa Tambakrejo Kabupaten Malang. Jurnal Ilmu Ekonomi, 1(1):16-29.

Astuti, Desi. 2015. Analisis Faktor-Faktor yang Mempengaruhi Pendapatan Nelayan di Kabupaten Langkat. Jurnal Ilmiah Integritas, 1(4): 110125.BPS Kabupaten Badung. 2015. Data hasil perikanan yang di jual di Tempat Pelelangan Ikan (TPI). Badung.

Cahyadi, Deddy, dan M. Pudjihardjo. 2017. Analisis Faktor-Faktor yang Mempengaruhi Pendapatan Driver Ojek Online (Studi Pada Go-Jek Malang). Skripsi Universitas Brawijaya, Malang.

Cunningham, Stephen. 1994. Fishermen's Incomes and Fisheries Management. Journal Marine Resource Economics, 9: pp. 241-252.

Dinas Peternakan, Perikanan dan Kelautan Kabupaten Badung. 2015. Data jumlah nelayan laut. Badung.

Frydenberg, Stein. 2011. Theory of Capital Tructure-a Review. Trondheim Business School - Norwegian University Of Science And Technology; Sor Trodelag University Collage-Trondheim Business School. Bulletin of Indonesia Economic Studies., 35(1)pp:16-17.

Gosyen, Tavi Supriana, dan Hasman Hasyim. 2015. Analisis Faktor-Faktor yang Mempengaruhi Pendapatan Nelayan. Journal On Social Economic Of 
Jurnal Satyagraha, Vol. 02, No. 02, Agustus 2019 - Januari 2020 ISSN :2620-6358

Agriculture and Agribusiness, 4(7):19.

Heryansyah, Muhammad S, and Syahnur S. 2013. An Analysis Of The Influence Factors Fishermen Productivity In East Aceh Regency. Jurnal Ilmu Ekonomi, Pascasarjana Universitas SyiahKuala, 1(2):9-15.

Jhingan, ML. 2003. Ekonomi Pembangunan dan Perencanaan. PT. Raja Grafindo :Padang Julindri, Asda Rauf, dan Amir Halid. 2016. Analisis Faktor-Faktor yang Mempengaruhi Hasil Tangkapan Nelayan di Kecamatan Bilato Kabupaten Gorontalo. Jurnal Ilmiah Agribisnis, 1(1): 44-50.

Kiranasari, 2010. Pengaruh Upah Per Bulan, Umur, Jenis Kelamin, Dan Jumlah Tanggungan Keluarga Terhadap Curahan Jam Kerja Sektor Informal Di Kabupaten Tegal. Skripsi Universitas Diponegoro Semarang.

Kartika, I Gusti Ayu, Made Suyana Utama, dan A.A.I.N Marhaeni. 2016. Pengaruh Faktor Ekonomi, Sosial, dan Demografi Terhadap Kontribusi Perempuan pada Pendapatan Keluarga di Sektor Informal Kecamatan Melaya, Kabupaten Jembrana. Jurnal PIRAMIDA, 12(1):38-47.

Martusa, Riki, dan Marsiana Jennie. 2012. Penerapan Biaya Standar Terhadap Pengendalian Biaya Produksi (Studi Kasus pada C.V SEJAHTERA BANDUNG). Jurnal Ilmiah Akuntansi, 7 (3). ISSN: 2086-4159.

Primyastanto, Mimit. 2015. Economic Analysis Of Pandega Fishermen Household At Madura Strait To Keep Food Security. International Journal of Oceans and Oceanography, 9(2): 97-104.

Raheman,Abdul and Nars, Muhamad. 2007. Working Capital Manajement and Profitability (Case of Pakistani Firm). Internasional Review of Business Research Papers, 3(1)pp:1-20.

Rahayu, Shabrina umi, Made Trisnawati. 2014. Analisis Pendapatan Keluarga Wanita Single Parent (Studi Kasus Kelurahan Sesetan, Kecamatan Denpasar Selatan, Kota Denpasar). Jurnal Ekonomi Kuantitatif Terapan, 7(2): 1084- 111.

Rahman, Rosyidah, Razi Apriansyah Mustaram, dan Masita. 2017. Pengaruh Modal, Tenaga Kerja Dan Jarak Tempuh Melalut Terhadap Pendapatan Nelayan Di Desa Pulau Kaung Kecamatan Buer Tahun 2016. Jurnal Ekonomi dan Bisnis, 14(2): 144-156.

Sahri, Muhammad, Soemarno, Efani A, and Zainal. A. 2014. Study on Entrepreneurship Spirit and Production Factors Affecting Sail Income of Madura Strait Fishermen. Jurnal International Journal of Civil \& Enviromental Engineering, 14(1), ISSN :2077-1258.

Suartawan, I Komang, dan I. B Purbadharmaja. 2017. Pengaruh Modal dan Bahan Baku Terhadap Pendapatan Melalui Produksi Pengrajin Patung Kayu Di Kecamatan Sukawati Kabupaten Gianyar. Jurnal Ekonomi Kuantitatif Terapan, 6(9): 1628-1657.

Teniwut, Wellem A. 2016. For Sustainable Revenue Of Fisheries Sector In Small Islands: Evidence Of Maluku, 
Jurnal Satyagraha, Vol. 02, No. 02, Agustus 2019 - Januari 2020 ISSN :2620-6358

Indonesia. Journal AACL Bioflux, 9(3): 722- 732.

Urmila, Made Heny, dan Ida Bagus Windu Wiyasa. 2017. Faktor-Faktor yang Mempengaruhi Pendapatan Melalui Curahan Jam Kerja Ibu Rumah Tangga Pengrajin Bambu di Kabupaten Bangli. Jurnal PIRAMIDA, 13(1):27-36.

Wulandari, Anak Agung Ratih, dan Ida Bagus Darsana. 2017. Pengaruh Modal, Tenaga Kerja, dan Lama Usaha Terhadap Pendapatan Pengrajin Industri Kerajinan Anyaman di Desa Bona Kecamatan Blahbatuh

Kabupaten Gianyar.E-Jurnal EP Unud, 6(4): 564-596.

Yanutya, Pukuh Ariga Tri. 2013. Analisis

Pendapatan Petani Tebu Di Kecamatan Jepon Kabupaten Blora. Economics Development Analysis Journal, 2(4): 286- 296. 